\title{
A SERIES OF SNAKE BITES
}

\author{
Lieutenant-Colonel W. E. I. FORSYTHE-JAUCH \\ M.A., M.B., B.Chir., D.T.M.\&H., A.M.B.I.M., R.A.M.C. \\ British Military Hospital, Dharan
}

\begin{abstract}
SUMMARY: Twenty-eight cases of snake bite, presumptive or proven are reported. Our experience at the British Military Hospital, Dharan showed that attempts to identify the types of snakes were of little value. Each case was treated expectantly, and energetic measures started once symptoms or signs developed.
\end{abstract}

\section{Introduction}

Most textbooks of general and tropical medicine deal with the treatment of snake bite. Almost all give detailed descriptions of the common poisonous snakes, how to identify them and the suspected lesion.

This study of snake bites was made because it was apparent that such textbook details appeared to bear little relevancy to practical matters here. In most cases the snakes were not seen at all, or so fleetingly that a useful description could not be obtained. The bites themselves showed a number of variations, with no obvious correlation between appearances and clinical developments.

\section{Background}

The cases described were all seen at the British Military Hospital, Dharan during the 1973 monsoon season. Dharan is in Kosi Zone, Eastern Nepal, latitude 27 and $28^{\circ} \mathrm{N}$, longitude 86 and $88^{\circ} \mathrm{W}, 1250$ feet above sea level, on the North Indian Plain just south of the Himalayan foothills. Dharan town, population 50,000 borders on the British Gurkha Cantonment in which the Military Hospital is situated. Immediately to the south there is a thick belt of jungle. To the east and west the country is agricultural. During the monsoon from June to October the temperature varies between 22.2 and $35.6^{\circ} \mathrm{C}$ and the humidity between 70 and 95 per cent.

\section{Pre-hospital details}

All but six of the patients were bitten during the hours of darkness (6 p.m. to 6 a.m.), and it is worth noting that house lighting in Dharan and in the villages is by paraffin lamps. It is understandable that few were able to describe the snake. The most that could be said was those which were seen in cases $3,4,14,20,22$ and 28, were probably not cobras. On the other hand the snake, which bit the patient case 28 , although on description suggested a grass snake, undoubtedly caused generalised symptoms. An identification chart of snakes commonly found in Nepal is not available, and even if it had been, would have been of little value. In this context it is interesting how widely authorities here vary in their identification of snake species. A snake killed outside the nurses quarters in the hospital was identified by local Nepali, Indian and British " experts" as cobra, cobra-type, krait and grass snake. In no instances were attempts made to catch snakes which had bitten. All snakes are greatly feared here, and the casualty's only interest is to get to hospital as quickly as possible. 
Which of the patients had really been bitten and which had but only scratched themselves and thought they were bitten is a matter of conjecture. In a few cases only were the typical puncture marks seen (cases 2, 12, 17, 26 and 27). Some of these patients developed local symptoms and one, case 2 systemic symptoms.

In all but three casualties the home first aid treatment of multiple tourniquets was used. It may be significant that of cases 1,10 and 16 who had no tourniquets applied, two died. No patients had sustained obvious limb or circulatory damage from their tight, sometimes triple tourniquets. This was probably because most casualties arrived at the hospital soon after injury. In only two cases had the bitten area been incised (cases 17 and 24) and the latter patient was locally infected.

\section{Course in hospital}

Upon admission to hospital home made tourniquets were removed and a skintight Singer tourniquet applied proximal to the wound. A history was taken, but as can be seen from Table I this was unhelpful in trying to decide what type of snake venom we could be dealing with. The site of injury was gently washed with Eusol, and quarter hourly observations were started: pulse, temperature, respiratory rate and blood pressure were checked. Haemorrhagic and neurological signs were searched for, and routine observations for developing signs were charted. The urine was tested routinely for blood. All the patients were frightened but none were clinically shocked. Most patients were surprised that antivenin was not administered immediately. However care was. taken to explain that most snakes were not poisonous, and that antivenin would be given if necessary. For reassurance the casualty was always shown the ampoules of antivenin. A mega dose of crystalline penicillin was given intramuscularly as was the first dose of tetanus toxoid. During the day the patient was usually observed in the casualty department; if signs more than minor local swelling developed, and at night, he was transferred to the ward.

All patients suffered local pain, sometimes numbness or tingling. In some cases this was probably psychogenic, though the congestion distal to the home made tourniquets was possibly the cause of the symptoms in many patients. Penicillin and tetanus toxoid were given and local symptoms responded satisfactorily. Blistering was seen in three instances as was local haemorrhage or bruising. In three patients neurological symptoms developed and in case 6 evidence of systemic bleeding. The two casualties brought in dead are presumed to have died of neurotoxin. One boy, case 4, was found to have pulmonary tuberculosis and was detained for treatment of that condition.

Four case reports are given to illustrate the series in Table I..

\section{Case 1}

\section{Case reports}

$\mathrm{KT}$, a male aged 12, bitten at 9 p.m. on right thumb in a shop at home in Dharan. The snake was not seen, but there were clear bite marks. A tourniquet was not applied at home. On arrival at hospital at 10 p.m. he was fully conscious with no cyanosis, but had difficulty in protruding his tongue. After a test dose $20 \mathrm{ml}$ of antivenin was given intravenously." He was unconscious by the time he was admitted to the ward." Cardiac arrest occurred three times during the night, and despite further antivenin," steriods and all possible attempts to resuscitate him, he died next morning at 10 a.m. 
Table I

Series of twenty-eight cases of snake bite

\begin{tabular}{|c|c|c|c|c|c|c|c|c|}
\hline $\begin{array}{l}\text { Case } \\
\text { No. }\end{array}$ & Sex & Age & $\begin{array}{c}\text { Place } \\
\text { where bitten }\end{array}$ & $\begin{array}{l}\text { Description } \\
\text { of snake }\end{array}$ & $\begin{array}{c}\text { Time } \\
\text { bitten }\end{array}$ & $\begin{array}{l}\text { Area } \\
\text { of bite }\end{array}$ & Signs and symptoms & Treatment \\
\hline 1 & $\mathbf{M}$ & 12 & Shop & None & $9 \mathrm{pm}$ & Thumb & Neurological & Antivenin \\
\hline 2 & M & 11 & Shop & None & $9 \mathrm{pm}$ & Heel & Neurological & Antivenin : \\
\hline 3 & $\mathbf{M}$ & 14 & Field & Black & $1 \mathrm{pm}$ & Leg & Swollen leg. & $\begin{array}{l}3 \text { hour } \\
\text { observation. }\end{array}$ \\
\hline 4 & $\mathbf{M}$ & 14 & Tree & $\begin{array}{l}\text { Light } \\
\text { coloured }\end{array}$ & $2 \mathrm{pm}$ & Hand & Local swelling & $\begin{array}{l}6 \text { hour } \\
\text { observation }\end{array}$ \\
\hline 5 & $F$ & 30 & House & None & $4 a m$ & Leg & Local bruising & $\begin{array}{l}6 \text { hour } \\
\text { observation }\end{array}$ \\
\hline 6 & $\mathbf{M}$ & 46 & Path & None & $7 \mathrm{pm}$ & Leg & $\begin{array}{l}\text { Swelling: Pyrexia } \\
101^{\circ} \mathrm{F} \text {. Haematuria }\end{array}$ & $\begin{array}{l}\text { Admission for } \\
7 \text { days }\end{array}$ \\
\hline 7 & $\mathbf{F}$ & 35 & Field & None & $8 \mathrm{pm}$ & Hand & Local pain & $\begin{array}{l}\text { Overnight } \\
\text { observation }\end{array}$ \\
\hline 8 & $\mathbf{M}$ & 40 & House & None & $8 \mathrm{pm}$ & Leg & Local pain & $\begin{array}{l}\text { Overnight } \\
\text { observation }\end{array}$ \\
\hline 9 & $F$ & 32 & House & None & $6.30 \mathrm{am}$ & Leg & $\begin{array}{l}\text { Local pain and } \\
\text { bruising. Pyrexia } \\
99.8^{\circ} \mathrm{F}\end{array}$ & $\begin{array}{l}6 \text { hour } \\
\text { observation }\end{array}$ \\
\hline 10 & $\mathbf{M}$ & 3 & Field & None & $2 \mathrm{pm}$ & Hand & $\begin{array}{l}\text { Local swelling. } \\
\text { Cyanosis }\end{array}$ & $\begin{array}{l}\text { Brought in } \\
\text { dead }\end{array}$ \\
\hline 11 & $\mathrm{~F}$ & 30 & Field & None & $9 \mathrm{pm}$. & Ankle & $\begin{array}{l}\text { Local swelling. } \\
\text { Shock }\end{array}$ & $\begin{array}{l}\text { Overnight } \\
\text { observation }\end{array}$ \\
\hline 12 & $\mathbf{F}$ & 45 & Field & None & $10 \mathrm{pm}$ & Leg & Local pain & $\begin{array}{l}\text { Overnight } \\
\text { observation }\end{array}$ \\
\hline 13 & $F$ & 7 & House & None & $7.30 \mathrm{pm}$ & Toe & Pain & $\begin{array}{l}6 \text { hour } \\
\text { observation }\end{array}$ \\
\hline 14 & $\mathbf{M}$ & 29 & Garden & Green & $9 \mathrm{pm}$ & Leg & Pain & $\begin{array}{l}3 \text { hour } \\
\text { observation }\end{array}$ \\
\hline 15 & $\mathbf{M}$ & 34 & House & None & $4 \mathrm{am}$ & Leg & $\begin{array}{l}\text { Local pain and } \\
\text { swelling: Pain } \\
\text { in chest. Dryness } \\
\text { of mouth. Blurring } \\
\text { of vision. }\end{array}$ & $\begin{array}{l}\text { Antivenin. } \\
36 \text { hour } \\
\text { observation }\end{array}$ \\
\hline 16 & $\mathrm{~F}$ & 65 & Path & None & $1.45 \mathrm{am}$ & Leg & None & $\begin{array}{l}\text { Brought in } \\
\text { dead }\end{array}$ \\
\hline 17 & $\mathbf{M}$ & 50 & House & None & $2 \mathrm{am}$ & Hand & Knifecuts & $\begin{array}{l}36 \text { hour } \\
\text { observation }\end{array}$ \\
\hline 18 & $F$ & 5 & Field & None & $6 \mathrm{pm}$ & Foot & Pain & $\begin{array}{l}\text { Overnight } \\
\text { observation }\end{array}$ \\
\hline 19 . & $\mathbf{M}$ & 40 & Fiẹld & None & $4 \mathrm{pm}$ & Foot & Paịn & $\begin{array}{l}\text { Overnight } \\
\text { observation }\end{array}$ \\
\hline 20 & $\mathbf{M}$ & 40 & House & White & $8 \mathrm{pm}$ & Toe & $\begin{array}{l}\text { Swelling pain. } \\
\text { Pyrexia } 100^{\circ} \mathrm{F}\end{array}$ & $\begin{array}{l}\text { Overnight } \\
\text { observation }\end{array}$ \\
\hline 21 & M & 7 & House & None & evening & Foot & Swelling and pain & $\begin{array}{l}\text { Ovérnight } \\
\text { observation }\end{array}$ \\
\hline
\end{tabular}


Table I (continued)

\begin{tabular}{|c|c|c|c|c|c|c|c|c|}
\hline $\begin{array}{l}\text { Case } \\
\text { No. }\end{array}$ & Sex & Age & $\begin{array}{c}\text { Place } \\
\text { where bitten }\end{array}$ & $\begin{array}{c}\text { Description } \\
\text { of snake }\end{array}$ & $\begin{array}{l}\text { Time } \\
\text { bitten }\end{array}$ & $\begin{array}{l}\text { Area } \\
\text { of bite }\end{array}$ & Signs and Symptoms & Treatment \\
\hline 22 & $\mathbf{M}$ & 40 & House & Brown & $5 \mathrm{am}$ & Ankle & Local haemorrhage & $\begin{array}{l}36 \text { hour } \\
\text { observation }\end{array}$ \\
\hline 23 & F & 30 & Field & None & $10 \mathrm{pm}$ & Toe & Local pain & $\begin{array}{l}\text { Overnight } \\
\text { observation }\end{array}$ \\
\hline 24 & M & 22 & Field & None & $8 \mathrm{pm}$ & Foot & $\begin{array}{l}\text { Multiple cuts. } \\
\text { swelling. } \\
\text { Pyrexia } 99^{\circ} \mathrm{F}\end{array}$ & $\begin{array}{l}36 \text { hour } \\
\text { observation }\end{array}$ \\
\hline .25 & $M$ & 40 & Field & None & $8 \dot{p m}$ & Ankle & $\begin{array}{l}\text { Local blistering. } \\
\text { Swelling. Pyrexia }\end{array}$ & $\begin{array}{l}36 \text { hour } \\
\text { observation }\end{array}$ \\
\hline 26 & F & 13 & House & None & $3 \mathrm{am}$ & Finger & $\begin{array}{l}\text { Bite. Swelling. } \\
\text { Pain locally. } \\
\text { Pulseless }\end{array}$ & $\begin{array}{l}8 \text { hour } \\
\text { observation }\end{array}$ \\
\hline 27 & $F$ & 30 & House & None & $5.30 \mathrm{am}$ & Thigh & Local swelling & $\begin{array}{l}6 \text { hour } \\
\text { observation }\end{array}$ \\
\hline 28 & $F$ & 25 & Field & Green & 9am & Finger & $\begin{array}{l}\text { Bite. Pain. Swelling. } \\
\text { Blistering, Giddy- } \\
\text { ness. Headache. } \\
\text { Pyrexia }\end{array}$ & $\begin{array}{l}\text { Overnight } \\
\text { observation }\end{array}$ \\
\hline
\end{tabular}

Case 2

LM, a male aged 11 , bitten on the foot in the same incident as case 1 . The snake was not seen and bite marks were not obvious. A tourniquet was not applied at home, but $5 \mathrm{ml}$ intravenous antivenin was given in Dharan before admission to the hospital. On arrival at the hospital at 1.25 a.m., three and a half hours after being bitten, he complained of diplopia, his speech was slurred, there was nystagmus and his pupils were dilated. A further intravenous $5 \mathrm{ml}$ of antivenin was given and the symptoms gradually wore off. At $1.30 \mathrm{p} . \mathrm{m}$. that day the patient complained of blurred vision and bilateral ptosis was noted, there was left facial paralysis and the patient felt drowsy. A further $10 \mathrm{ml}$ intravenous antivenin was given. $\mathrm{He}$ became asymptomatic within the next twenty-four hours.

Case 6

IN, a male aged 46, from Kerabari, 30 miles from Dharan. Bitten on the right ankle at $7 \mathrm{p}$.m. walking along a path two hours' walk from his village, the snake was not seen. He applied a mid-calf tourniquet and walked home, and slept with the tourniquet on. He then put on another mid-calf tourniquet before leaving for the hospital. He arrived twenty-four hours after being injured. The whole leg was oedematous. Bite marks were clearly visible. The patient was treated expectantly, and apart from transient haematuria and pyrexia, maximum $101^{\circ} \mathrm{F}$, no other systemic involvement became apparent. He was mobilised gradually and was discharged after 7 days in hospital.

Case 10

$\mathrm{SC}$, a male aged 3 from Ghopa, near Dharan. This child's father was working in the fields some way from home, the child playing nearby. The child put his hand into a 
hole and was apparently bitten, the snake was not seen. A tourniquet was not applied and the father ran for one and a half hours to the hospital carrying his son, who died just before arriving at the hospital. The only signs were a single puncture mark over a vein on the dorsum of the hand, and cyanosis of the lips. It must be assumed that this child had received an intravenous dose of venom.

\section{Snakes found in Dharan}

Specimens of snakes kept in the British Military Hospital, using Gharpuroy (1935) as a guide, have been identified (Table II). However it is noteworthy that none of the

\section{Table II}

Poisonous snakes found in Dharan

\begin{tabular}{|c|c|c|c|c|c|}
\hline Species & Type & Length & Colour & Markings & Effect of venom \\
\hline \multirow[t]{3}{*}{ Vipers } & Russel & $3-5$ feet & Buff to brown & $\begin{array}{l}\text { Black spots } \\
\text { solid or hollow }\end{array}$ & $\begin{array}{l}\text { Swelling, blistering, } \\
\text { sloughing }\end{array}$ \\
\hline & $\begin{array}{l}\text { Common green } \\
\text { (Bamboo snake) }\end{array}$ & $2-3$ feet & $\begin{array}{l}\text { yellow, green, } \\
\text { brown }\end{array}$ & $\begin{array}{l}\text { Yellow or } \\
\text { white line on } \\
\text { flanks }\end{array}$ & $\begin{array}{l}\text { Swelling, nausea, } \\
\text { vomiting, pyrexia }\end{array}$ \\
\hline & $\begin{array}{l}\text { Brown } \\
\text { Himalayan }\end{array}$ & 2 feet & Brown & Mottling & $\begin{array}{l}\text { Swelling, nausea, } \\
\text { vomiting, pyrexia }\end{array}$ \\
\hline \multirow[t]{2}{*}{ Cobras } & Indian & $6-8$ feet & $\begin{array}{l}\text { White, buff, } \\
\text { brown, black }\end{array}$ & $\begin{array}{l}\text { Hood and } \\
\text { spectacle } \\
\text { marking }\end{array}$ & Neurotoxic \\
\hline & King & $8-15$ feet & $\begin{array}{l}\text { Yellow, green, } \\
\text { brown, black }\end{array}$ & $\begin{array}{l}\text { Hood and } \\
\text { spectacle } \\
\text { marking }\end{array}$ & Neurotoxic \\
\hline \multirow[t]{2}{*}{ Kraits } & Common & $3-4$ feet & Black & $\begin{array}{l}\text { Narrow white } \\
\text { bands }\end{array}$ & $\begin{array}{l}\text { Neurotoxic and } \\
\text { haemorrhagic }\end{array}$ \\
\hline & Banded & 5-6 feet & Black & $\begin{array}{l}\text { Broad white } \\
\text { bands }\end{array}$ & $\begin{array}{l}\text { Neurotoxic and } \\
\text { haemorrhagic }\end{array}$ \\
\hline
\end{tabular}

snakes caught in the Cantonment were killed after biting a person. Those people bitten and listed in Table $I$ all received their injury outside the Cantonment, and on no occasion was the culprit snake killed, nor was a remotely reliable opinion on the nature of the snake obtained.

\section{Discussion}

The snake bite series described is one based upon recent practical experience. Our findings differ in some respects from the facts as taught academically. No reliance could be placed upon a description because the snake was not usually seen and never caught. Most cases occurred during the night and a fair number of bites were on the hands, in both respects differing from Reid (1972). Local signs are obscured by swelling caused by home made tourniquets, and the typical fang-marks were rarely seen.

With so little to be gained from the history or from the initial symptoms and signs; treatment had to be expectant, except in the two cases where neurological involvement 
was already obvious upon admission. Events proved the soundness of this policy, and the risks of unnecessary antivenin administration were avoided. The first priority is the application of a skin-tight tourniquet. Each case was observed for at least six hours, antivenin being given if neurological or marked general haematological symptoms developed. Symptoms localised to the injured limb would not appear to warrant administration of antivenin; analgesics and antihistamines usually relieved the symptoms and penicillin and tetanus toxoid were always given prophylactically. All patients discharged after observation were advised to return in the unlikely event of anything untoward developing. There is no doubt that they would have come back had this been necessary, but none did, except for their follow-up antitetanus injections.

\section{Conclusion}

The British Military Hospital, Dharan is the last hospital in the Army where almost the entire spectrum of tropical diseases and injuries can be seen. Important amongst these are snake bite injuries. The series studied shows the importance of applying first principles in the treatment of this condition.

\section{Acknowledgements}

Only a proportion of the cases listed were treated personally by the writer. All the medical officers at the British Military Hospital have had occasion to deal with snake. bites.

REID, H. A. (1972). Tropical Doctor 2, 4.

\section{REFERENCES}

Gharpuroy, K. G. (1935). The Snakes of India. Bombay Press.

\section{Honorary Consultants}

To the Army

Professor J. B. E. Baker, M.A., B.Sc., B.M., B.Ch., has been appointed Honorary Consultant in Pharmacology to the Army with effect from 1 September 1974, in succession to Professor H. C. Stewart, who has retired.

Mr. J. P. Williams, M.Chir., F.R.C.S., has been appointed Honorary Consultant in Urology to the Army with effect from 27 July 1974, in succession to Mr. H. G. Hanley who has retired. 